\title{
The Energy Storage Business Model within Electricity Companies
}

\author{
Juliana D'Angela Mariano ${ }^{1,2}$, Patrícia Monteiro Barbosa de Freitas², Lúcio de Medeiros², \\ Pedro Augusto Biasuz Block ${ }^{2}$, Victor Baiochi Riboldi ${ }^{3}$, Jair Urbanetz Junior ${ }^{1}$ \\ ${ }^{1}$ Federal University of Technology - Paraná \\ 3165 Avenida Sete de Setembro, Curitiba, Brazil \\ juliana.mariano@lactec.org.br; urbanetz@utfpr.edu.br \\ ${ }^{2}$ Lactec \\ 8813 Rod. BR-116, km 98, Curitiba, Brazil \\ patricia.freitas@lactec.org.br; lucio.medeiros@lactec.org.br; pedro.block@lactec.org.br \\ ${ }^{3}$ CPFL Energia \\ 1755 Rod. Eng. Miguel Noel Nascentes Burnier, Campinas, Brazil \\ riboldi@cpfl.com.br
}

\begin{abstract}
Sustainability transitions have caused major changes in the energy sector which has drove electricity companies to seek new processes, products, and services. Within this context, business models are conceptual tools that express business logic. Furthermore, they consist of a value proposition in services that at the same time generates benefits for consumers of energy and revenue for these companies. This work aims to show one of the innovations in the electricity company in Brazil - CPFL Energia, which is the third biggest Brazilian electricity utility company, as well as its presentation through the development of three Canvas business models. The methodology was a literature review on the proposed theme through a bibliometric analysis. The single case methodology was applied to target: residential and industrial consumers with hour-seasonal tariffs. The study concluded that for it to become economically viable, electricity regulatory evolution is necessary which encourages the use of energy storage systems. Furthermore, industrial consumers still have the benefit of reducing the energy demand contract.
\end{abstract}

Keywords: Value Proposition, Business Model, Demand Reduction

\section{Introduction}

The energy sector has undergone major changes due to transitions from renewable energies, which has made the energy utilities search for new processes, products and services increasingly aligned with the needs of their consumers. In this sense, the business model consists of a tool related to the company's logic, and how they operate and create value for their stakeholders using new technologies $[1,2]$.

In the case of electricity companies, the creation of value can be the offer of innovative services that generate benefits for consumers and revenue for these companies. Activities such as the sale, installation, and maintenance of energy storage systems can bring benefits to consumers in reducing the electric bill which aims to keep energy costs low, as well as reducing energy demand contracts. The development of a portfolio of products and services, the characteristics of the business model and technological aspects result in different degrees of innovation $[1,2]$.

Since the business model is an abstraction about how a company should operate and how the organization creates, captures, and delivers value it is essential to be understood by all parties involved in the innovation of the value proposition. [3]. The business model is different from the business plan, and it does not account for the uncertainty within the environment. In addition, they are static and with future forecasts that many times cannot be fulfilled, while the Business Models are dynamic, more agile, flexible, and productive which is frequently used in start-ups [4].

The complexity of managing projects in the modern world has shown that current practices are linked to mechanical, linear, and bureaucratic models. There is difficulty with aspects of organizational complexity such as change control for example enhancing risks and failures, communication, and quality management problems, and therefore are not adhering to this new context. Tools like this have already become the object of research in other contexts in the area such as portfolio management [5]. 
Faced with this challenge, techniques, and visual tools, known as the Canvas approach, are emerging with the purpose of generating greater flexibility and simplicity in project management practices [6]. The most recent initiative was received well by entrepreneurs and is the synthesis of the company's functions in a single framework. It is the result of studies and experiments carried out by Alex Osterwalder and Yves Pigneur [4, 7].

In Canvas the main characteristic is the graphic format and the use of notepads, which serves as a tool to record the fundamental activities of the process. Additionally, they promote the reuse of information from one project to another, have areas or containers with specific objectives to be filled by the team. Despite the existence of several types of Canvas, its application with project managers, developers and innovators is uninformed and misguided due to the lack of knowledge of the potential of this approach [8]. However, as Canvas is something practical it is possible to bring together the team of entrepreneurs to discuss the main components of the business, test hypotheses and gradually evolve the business concept, and produce new versions of Canvas through a visual tool [9].

\section{Business Model Methodology}

The activities of this stage consisted of a survey on the theory of the Canvas approach using the methodology of a single case study being the target audience: residential and industrial consumers with hours-seasonal tariffs. The objective is to map one of the innovations in the company as well as its presentation through the elaboration of three business models using the Canvas approach. This methodology was used in the research which was a bibliographic review on the proposed theme through a bibliometric analysis in the bibliographic platforms of Scopus, and ScienceDirect among other agencies in the energy sector. There is no temporary limitation on publications. During the construction of a Business Model, it is possible to observe the flow of the value proposal through all areas of the company such as hypothesis planning, value proposition services, customer follow-up, customers relationship, channels, revenue flow sources, key partnerships, key feature, and cost structure described below according to Alex Osterwalder and Yves Pigneur [7].

Hypothesis planning consists in the hypotheses proposed to complete each of the blocks of the Business Model Canvas methodology are identified and described. For the formulation of the hypotheses each of the blocks were developed, then identified the potential customers of the storage systems value chain and described the main differential attributes of this technology.

Value proposition (services) must solve a problem of a customer segment or satisfy a need, and this is the goal that entrepreneurs should keep in mind when analyzing this component of the business model. One must think about which products and / or services are being offered to each group of customers and the associated values. Values can be both quantitative and qualitative [7].

In this sense, the value proposition are the differential attributes that energy storage technology presents. These systems can provide back-up, to attend to the failure of the generating unit, leveling the daily load curve (load-leveling), and the reduction in peak demand (peak shaving). This results in savings for the consumer and the spinning reserve to allow continuity of supply after the unexpected loss of part of the generation, and for the maintained power quality of the transmission and distribution networks.

Customer segments creates market opportunities and there must be a relationship between the customer's hypotheses and the value proposition, so that the technology developed provides a solution to the problems and needs of the users in the sector to which the technology will be directed.

A business model can contain one or more distinct customer segments. According to [7], the company must have different groups of customers if the needs of such groups are different justifying different offers for each group so the distribution channels which reach these groups will also be different.

Regarding the electricity companies that designs and integrates its own electronic energy and management systems, it is currently positioned in the three-central links of the value chain. Energy storage system (ESS) using batteries and control systems are purchased from international suppliers. As a result, residential and industrial consumers with hourseasonal tariffs were identified as potential customers.

Customers Relationship present different categories ranging from personal assistance to automated services. Regardless of the form of the relationship, it will aim at winning new customers or retaining existing customers. In underexplored markets, the relationship is usually guided by aggressive customer acquisition strategies. In saturated markets, on the other hand, customer retention and the increase in average profitability per customer becomes more important [7]. 
Channels are the customer's point of contact with the company and therefore when analysing this component of the business model it is necessary to consider all channels of the company's interface with the customer whether communication, distribution, or sales [7].

Revenue Flow (Sources) are sources of income that companies can have such as: product sales, usage fee, monthly subscription, rent, advertisements, intermediation, etc. It is realized that the sources of revenue can be grouped into two groups: income from single payments, and recurring income, which are the result of constant payments [7].

Key partnerships are the collaboration that companies form partnerships for different reasons: to optimize the risks of their business models, and to facilitate the acquisition of resources, etc. One can distinguish between four types of partnerships: strategic alliances between non-competitors, competition: strategic partnerships between competitors, joint ventures to develop new businesses, and the buyer-supplier relationship to ensure reliable supplies [7].

Key feature is classified by Osterwalder and Pigneur [7] as the main resources for a business to function as physical: which includes factories, buildings, vehicles, stores, inventories, etc., intellectual: in this group there are brands, patents, databases, expertise in a certain sector, etc.; human: especially important for industries that depend on innovation and specialized knowledge, such as software companies; financial: does the company need third party capital to start the business? What is the capital required to start a new project? These and other questions must be answered when thinking about the financial aspect.

Cost structure are expenses that the company will have to offer its value proposition to the market, establish partnerships, and maintain relationships with customers among other things. As a rule, costs must be minimized in any business model, but for some companies having a low-cost structure is essential as they are cost driven businesses, which normally make extensive use of automation and outsourcing. On the other hand, there are also companies that are driven by value, and the concern with the reduction of costs exists, but the focus is on creating value. Usually, there are business models in this group with customized value proposals according to each customer segment [7].

\section{Electricity Companies Business Model}

This section describes three business models which is developed with their respective descriptions. In the case of CPFL Energia services are proposed with the application of energy storage by batteries: frequency regulation, voltage regulation, the postponement to reinforce the electric network, the firm capacity for intermittent sources which are solar and wind, and the reactive control which only applies to medium-sized batteries [10].

Consumers in Brazil fall into two broad groups: 1) free consumers who bilaterally negotiate for energy and pay regulated charges (or network tariffs) for access to distribution and transmission networks, and 2) regulated consumers who purchase energy at a controlled price derived from supply-contract auctions and pay the network tariff. There are large consumers connected directly to the transmission network that do not pay charges for distribution networks. Regulated consumers account for approximately $70 \%$ of the energy consumption [11].

As for the customers segment, the different consumer groups that CPFL Energia seeks to reach, and serve are defined: captive low voltage (LV) customers from CPFL, captive medium voltage (MV), and customers of CPFL and free customers.

Regarding the other blocks of the Canvas model, these were defined according to each CPFL segment described below. Table 1 shows the first business model, and its premise is directed at CPFL Solutions.

The customized solution can guarantee greater technical feasibility for the customer. The value proposal consists of a solution for the management of batteries integrated as a source of renewable energy in residential and industrial consumers. The customers will have a reduction in their energy bill and with that difference will be able to finance their system. The system will be installed, programmed, and maintained by CPFL Solutions and initially during the financing period. The technical benefit is obtained by the minimized the reverse power flow, and the reduced demand, which means the postponement of investments for the reinforcement of the electrical network. Industrial consumers can define their energy demand through a blue and green tariff (industrial time-of-use), whereas the commercial and residential can have a flat or white (residential time-of-use) tariffs. 
Table 1: Battery management solution 1.

\begin{tabular}{|c|c|c|c|c|}
\hline PARTNERSHIP & KEY-FEATURES & VALUE PROPOSITION & COSTUMERS RELATIONSHIP & CUSTOMER SEGMENTS \\
\hline \multirow[t]{3}{*}{$\begin{array}{l}\text { National manufacturers of power } \\
\text { converters and batteries. Research } \\
\text { Institutes and Universities. }\end{array}$} & $\begin{array}{c}\text { Training of the technical team in the design, } \\
\text { assembly and maintenance of ESSs. } \\
\text { Investment in consultancy specialized in } \\
\text { control and optimization systems. Design and } \\
\text { implementation of smart grids. }\end{array}$ & \multirow[t]{3}{*}{$\begin{array}{l}\text { Solution for battery management of } \\
\text { residential and industrial consumers. }\end{array}$} & $\begin{array}{c}\text { Customized solution for each consumption } \\
\text { profile. Evaluation of the estimated return } \\
\text { known to this profile. Installation, operation } \\
\text { and maintenance of the solution during } \\
\text { financing. }\end{array}$ & \multirow[t]{3}{*}{$\begin{array}{l}\text { Captive customers of CPFL } \\
\text { Industrial, Residential and } \\
\text { Commercial. Tariffs: Blue, } \\
\text { Green and White. }\end{array}$} \\
\hline & REVENUE FLOW & & CHANNELS & \\
\hline & $\begin{array}{l}\text { Training of the technical team. Laboratory } \\
\text { infrastructure. Supervision and control } \\
\text { infrastructure. Telecom infrastructure. }\end{array}$ & & $\begin{array}{l}\text { Proposal along with the energy bill. } \\
\text { Electricity company's web page. }\end{array}$ & \\
\hline \multicolumn{2}{|r|}{ COST STRUCTURE } & \multicolumn{3}{|c|}{ REVENUE SOURCES } \\
\hline \multicolumn{2}{|r|}{$\begin{array}{l}\text { Equipment cost. } \\
\text { Salaries of the teams involved. } \\
\text { Unvoiced energy. }\end{array}$} & \multicolumn{3}{|c|}{$\begin{array}{l}\text { Postponement of network reinforcements and investments for possible adaptations due to } \\
\text { the massive use of uncontrolled renewable energy sources. Financing paid on the energy bill } \\
\text { with attractive interest rate for the consumer. }\end{array}$} \\
\hline
\end{tabular}

Table 2, the suggested business model is again for CPFL Solutions. It was built from the value proposal defined as Ancillary Services (voltage regulation, frequency regulation, and reactive control). The delivery of value to the Customer Segment will be carried out through the sale or rent of the energy storage system (ESS) to the customer. CPFL will attract these customers by carrying out technical and commercial studies. Also, you can make a prospectus for free customers who have similar problems to the concessionaire's captive customers.

Table 2: Ancillary services.

\begin{tabular}{|c|c|c|c|c|}
\hline PARTNERSHIP & KEY-FEATURES & VALUE PROPOSITION & COSTUMERS RELATIONSHIP & CUSTOMER SEGMENTS \\
\hline \multirow[t]{3}{*}{$\begin{array}{c}\text { ESS Suppliers } \\
\text { ESS Developers } \\
\text { Internal and External R\&D } \\
\text { Companies to Recycle the Batteries }\end{array}$} & $\begin{array}{c}\text { System Sizing } \\
\text { ESS Import } \\
\text { Technical Assistance } \\
\text { Training and Training of the Technical and } \\
\text { Commercial Team }\end{array}$ & \multirow[t]{3}{*}{ Ancillary Services } & $\begin{array}{c}\text { ESS Personalized } \\
\text { ESS Tested and Validated } \\
\text { Personalized Service } \\
\text { Warranty Service } \\
\text { Technological Update } \\
\text { Reducing Costs with ESS Large-Scale }\end{array}$ & \multirow[t]{3}{*}{$\begin{array}{l}\text { Captive Customers of MV } \\
\text { Free Customers }\end{array}$} \\
\hline & REVENUE FLOW & & CHANNELS & \\
\hline & $\begin{array}{c}\text { Specialized Technical and Commercial Team } \\
\text { ESS Equipment Logistics }\end{array}$ & & $\begin{array}{l}\text { Segmented Sales Teams } \\
\text { Electricity Company Specific Apps } \\
\text { Concessionaire 's Web Page }\end{array}$ & \\
\hline \multicolumn{3}{|c|}{ COST STRUCTURE } & \multicolumn{2}{|c|}{ REVENUE SOURCES } \\
\hline \multicolumn{3}{|c|}{$\begin{array}{c}\text { Sales and Technical Assistance Team } \\
\text { Equipment } \\
\text { Commissioning } \\
\text { Decommissioning } \\
\text { Sales and Delivery Logistics }\end{array}$} & \multicolumn{2}{|c|}{$\begin{array}{l}\text { Installation and Maintenance Rate } \\
\text { ESS Rental } \\
\text { Financing of Equipment } \\
\text { Equipment Leasing }\end{array}$} \\
\hline
\end{tabular}

Table 3 is the business model for CPFL Services. Value proposition consists of the sale, installation, and maintenance of energy storage systems. The target audience is the residential and industrial consumers with hourseasonal tariffs. To become economically viable regulatory evolution is necessary which encourages the use of energy storage systems. Industrial consumers still have the benefit of reducing the demand contract. 
Table 3: Battery management solution 2.

\begin{tabular}{|c|c|c|c|c|}
\hline PARTNERSHIP & KEY-FEATURES & VALUE PROPOSITION & COSTUMERS RELATIONSHIP & CUSTOMER SEGMENTS \\
\hline \multirow[t]{2}{*}{$\begin{array}{l}\text { National manufacturers of power } \\
\text { converters and batteries. Research } \\
\text { Institutes and Universities. }\end{array}$} & $\begin{array}{l}\text { Training of the technical team in the design, } \\
\text { assembly and maintenance of ESSs. } \\
\text { Investment in consultancy specialized in } \\
\text { control and optimization systems. Design and } \\
\text { implementation of smart grids. }\end{array}$ & \multirow[t]{2}{*}{$\begin{array}{l}\text { Solution for battery } \\
\text { management of residential } \\
\text { and industrial consumers. }\end{array}$} & $\begin{array}{c}\text { Customized solution for each consumption } \\
\text { profile. Evaluation of the estimated return } \\
\text { known to this profile. Installation, operation } \\
\text { and maintenance of the solution during } \\
\text { financing. }\end{array}$ & \multirow[t]{2}{*}{$\begin{array}{l}\text { Captive customers of CPFL } \\
\text { Industrial, Residential and } \\
\text { Commercial. Tariffs: Blue, } \\
\text { Green and White. }\end{array}$} \\
\hline & \begin{tabular}{|c|} 
REVENUE FLOW \\
Training of the technical team. Laboratory \\
infrastructure. Supervision and control \\
infrastructure. Telecom infrastructure.
\end{tabular} & & $\begin{array}{l}\text { Proposal along with the energy bill. } \\
\text { Electricity company's web page. }\end{array}$ & \\
\hline \multicolumn{2}{|r|}{ COST STRUCTURE } & & \multicolumn{2}{|l|}{ REVENUE SOURCES } \\
\hline \multicolumn{2}{|r|}{$\begin{array}{l}\text { Equipment cost. } \\
\text { Salaries of the teams involved. } \\
\text { Unvoiced energy. }\end{array}$} & & \multicolumn{2}{|c|}{$\begin{array}{l}\text { Postponement of network reinforcements and investments for possible } \\
\text { adaptations due to the massive use of uncontrolled renewable energy sources. } \\
\text { Financing paid on the energy bill with attractive interest rate for the consumer. }\end{array}$} \\
\hline
\end{tabular}

Therefore, as seen with the theoretical review of the business model using the Canvas approach, the elaboration of the table requires annotations performed by the entire team to act as a tool to record the fundamental activities of the process. In addition, it is possible to promote the reuse of information from one project to another among the Lactec and CPFL teams. The business models developed are aligned with the objectives of the electricity company, which aims to promote business in a strategic and competitive manner. Therefore, it allows for the models to maintain its dynamics and vitality.

\section{Conclusion}

Business models are to be implemented which creates a change in the regulatory framework that is necessary, since it is not possible to define the types of services allowed for each participant in the electrical system. Furthermore, there are still no well-established rules that regulate the ways to commercialize energy from storage systems, and some countries are testing for the implementation of possible uses.

The sale of energy also depends on the market in which it operates. The energy can be sold by different market players which imposes complexities in the process. Therefore, the business models developed allow for subsequent adaptations to meet the electricity company demands. The study concluded that for it to become a reality regulatory evolution is necessary, which encourages the use of energy storage systems in the listed consumers.

Is important to highlight this study reflects initial results and proposes since the team is still refining the study. Future research and work will aim to reformulate the Brazilian Electricity Regulatory Agency (ANEEL) regulations for the use of the storage system in distribution and promotes its use in the Brazilian electricity sector.

\section{Acknowledgements}

The authors would like to thank the Lactec and CPFL Energia that supported the research through the ANEEL R\&D program (PD-02937-3018/2016) entitled PA3018 - "Implementation, Development and Analysis of Applications of Energy Storage Technologies in the Operation of CPFL Distribution Networks. The authors also thank UTFPR for the support and infrastructure provided for the development of this research.

\section{References}

[1] M. A. Macedo, P. A. C. Miguel, N. Casarotto Filho, "A caracterização do design thinking como um modelo de inovação". RAI Revista de Administração e Inovação, vol. 12, no. 3, pp. 157-182, 2015.

[2] L. C. M. Teixeira, H. E. G. Lopes, "Aplicação do modelo canvas para o modelo de negócios do Banco do Brasil e da Caixa Econômica Federal”. Revista Gestão \& Tecnologia, vol. 16, no. 2, pp. 73-99, 2016.

[3] L. M. Queiros, D. S. Da Silveira, J. da S. Correia-Neto, and G. Vilar, "LODPRO: learning objects development process". Journal of the Brazilian Computer Society, vol. 22, no. 1, pp. 3, 2016. 
[4] T. R. Alves, J. C. Duarte, “A utilização do modelo de negócios e plano de negócios pelas startups”. Caderno PAIC, vol. 17, no. 1, pp. 117-130, 2016.

[5] B. C. Medeiros, V. F. da S. Araújo, M. K. de Almeida, and S. Oliveira, "Life Cycle Canvas (LCC): Um modelo visual para a gestão do ciclo de vida do projeto". Revista de Gestão e Projetos-GeP, vol. 9, no. 1, pp. 87-101, 2018.

[6] B. C. Medeiros, M. V. de Sousa Neto, A. C. dos Santos Nobre, and G. M. F. Nogueira, "Planejando projetos com o Life Cycle Canvas (LCC): um estudo sobre um projeto de infraestrutura pública estadual". Exacta, vol. 15, no. 1, pp. 155$170,2017$.

[7] A. Osterwalder, Y. Pigneur, "Business model generation: inovação em modelos de negócios". Alta Books Editora, 2013.

[8] M. de Oliveira Morais, I. G. Júnior, P. L. O. C. Neto, and R. F. Gonçalves. "Análise de um projeto de inovação tecnológica e o uso abordagem canvas". Iberoamerican Journal of Project Management, vol. 8, no. 1, pp. 14-26, 2017.

[9] F. B. S. Nardes, R. C. da Rocha Miranda, "Lean Startup e Canvas: uma proposta de metodologia para startups". Revista Brasileira de Administração Científica, vol. 5, no. 3, pp. 252-272, 2014.

[10] M. Jiménez Pijoán, "Sistema híbrido de almacenamiento energético y su integración en el Smart grid." Bachelor's thesis, Dept. Electronic and Telecom. Autonomous University of Madrid. 2015.

[11] R. Moreno, B. Bezerra, H. Rudnick, C. Suazo-Martinez, M. Carvalho, A. Navarro, C. Silva, and G. Strbac. "Distribution Network Rate Making in Latin America: An Evolving Landscape." IEEE Power and Energy Magazine, vol. 18, no. 3, pp. 33-48, 2020. 